\title{
Hendrick Peter Scholte and the Land of Promise
}

\author{
RONALD D. RIETVELD
}

Dutch Immigration to Iowa began with the settlement of Pella in the summer of 1847. In that year; a group of eight hundred emigrants left Holland in search of economic opportunity and religious freedom under the leadership of the Dominee Hendrik Peter Scholte, a firm opponent of compulsory membership in the Dutch state church. Over ten years of persecution for their dissenting religious beliefs had prompted the Hollanders to emigrate. As early as 1835 Scholte had warned King William I, "My fellow believers might be forced to seek a place in the world to serve.God according to the dictates of their consciences. ${ }^{11}$ With continued persecution by the national clergy, the resolute Dutch pastor again warned "that God might yet prepare a Pella for his oppressed people, when the judgment of God shall come over our Fatherland." 2

Yet for ten years Scholte, patriotic and personally loyal to the House of Orange, resisted the temptation to flee and struggled with his conscience which dictated that he fight for a religious revival in his homeland. Finally, he settled these personal conflicts and "firmly resolved to leave the Netherlands with his flock and adopt the United States as a new fatherland. ${ }^{3}$ Choosing Iowa as the site of their settlement, Scholte and a few close associates purchased 47,000 acres in Marion County and

'H. P. Scholte, ed., De Reformatie, 1, I (1837), 457.

${ }^{2}$ H. P. Scholte to King. Willem I, 16 October 1835, Scholte Papers, Central College Archives, Pella, Iowa (hereafter cited as Scholte Papers).

${ }^{3} \mathrm{~K}$. Van Stigt, History of Pella, translated by Elizabeth Kempkes (Pella: Weekblad Drukkerij, 1897), 41; Jacob Vander Zee, The Hollanders of Iowa (lowa City, 1912), 39. 
founded the town of Pella, which is still the center of Dutch culture in the state.

Scholte was part of a general movement in the Netherlands founded by the Dutch poet William Bilderdijk (1795-1831). In the early nineteenth century Bilderdijk laid the foundations for the Dutch Reveil, a conservative theological, philosophical, and political movement. Bilderdijk repudiated eighteenth-century Enlightenment thought, including the revolutionary spirit which swept Europe after the French Revolution and brought so much misery to the Netherlands. Instead he encouraged the revival of Dutch Calvinism in church, school, and government. Those Dutch aristocrats who gloried in "Nederland en Orange" found the source of Europe's decadence in the American Revolution, and saw America as a despised and wild place, overwhelmed by "individualism and individuals." ${ }^{\text {" }}$

Bilderdijk read scripture and discussed theological issues with a small group in Amsterdam. He exhorted his followers to devotion and sorrow over the spiritual decay in the state Reformed Church. One of these disciples, Isaac Da Costa, introduced young Hendrik Scholte to Bilderdijk shortly before the poet's death in 1831 and their brief friendship profoundly influenced Scholte. Bilderdijk wrote in Scholte's album when Scholte volunteered for the Netherland's campaign against the rebelling Belgians in 1830. Scholte cherished Bilderdijk's pencil box and the complete set of his works which the Dutch poet himself presented to his young friend. ${ }^{5}$ After Bilderdijk's death, Da Costa continued the conservative philosophical tradition and became Scholte's mentor. Da Costa proclaimed the need for a Holy Holland, inspiring hope for a great Calvinistic revival. With his spiritual leaders, young Scholte shared visions of a redeemed nation. ${ }^{6}$

At his ascension to the throne in 1814, William I had turned his attention to the state church which had suffered great humiliation in the hands of Napoleon and was anxious to return to royal favor. The King attempted to regulate the church, appoint-

${ }^{4}$ Henry S. Lucas, Netherlanders in America (Ann Arbor, 1955), 44; L. Oostendorp, H. P. Scholte (Franeker, the Netherlands, 1964), 147-148.

${ }^{5}$ J. C. Rullman, De Afscheiding (Amsterdam, 1922), 99-100; Oostendorp, Scholte, 30 .

${ }^{6}$ Oostendorp, Ibid., 147-148; Groen van Prinsterer en zijn tijd, I, 131. 
ing a central administrative board; the board proscribed maintenance of the creed as embodied in the Dutch Confession of Faith, the Heidelberg Cathechism, and the Doctrinal Rules of the Synod of Dort of 1618 .

Yet by 1834 scores of orthodox, conservative Christians throughout the country seceded from the state church and formed small independent congregations to protest growing irregularities and widespread doctrinal deviation. Scholte was among these separatists. The state church declared him, along with other seceding clergy, unsuitable and unworthy to preach their "evangelical" persuasions. They did not stop nor were they deserted by their congregations. The seceders suffered under the Code Napoleon which forbade assemblies of more than twenty people without a license from local authorities. The police dispersed local meetings and punished the separatists with fines and imprisonment. Scholte suffered military watches and imprisonments and paid fines and court costs amounting to $\$ 3,200$. Individual Hollanders, especially the national clergy, joined the government in tormenting the dissenters. Scholte complained he had been hit with stones and fists and had heard a mob cry out, "Kill him, kill him!"7

For some time Scholte resisted the idea of emigration, especially with material gain as a motive. He believed that the Netherlands needed the separatists to lead a religious revival. Therefore, in 1836 he dissuaded a group at Vlissingen (Flushing) in southern Holland from migrating. He continued, however, to gather favorable opinions about the people and government of the United States. He followed the status of religious bodies in the United States, carefully analyzed church-state relations, and in 1845 compared conditions in the Netherlands unfavorably with the freedoms enjoyed by various religious bodies in the United States. ${ }^{8}$

The daily persecution was further aggravated by economic conditions: declining trade, decreased wages, unscrupulous competition, and exhaustive taxation. As Scholte later wrote,

${ }^{7}$ Vander Zee, Hollanders of Iowa, 33.

${ }^{8}$ H. P. Scholte to J. H. Budding, J. H. Gunning, H. J. Budding: Leven en Arbeid (Rhenen, 1909), 482; H. P. Scholte, "Kerk en Staat en Ontwikkeling van derzelver Scheiding in de Verseenigde Staaten van Noord Amerika," De Reformatie, Series II (1845), 213-225, 279-292, 305-323. 
"the conviction that the social condition of the old country was such, that there was no opportunity for the honest poor and for men of small means to better their condition or to sustain themselves and families. ..." Although he did not think that conditions in the Netherlands made emigration inevitable, he acknowledged that if the situation did not change a Christian soon could not engage in any business without offending his conscience. Scholte could not ignore the increasing poverty of his fellow Hollanders and he saw no possibility of relief from it. Slowly the separatist pastors, including Scholte, had begun to think of beginning a new life where they could worship freely and not have to wait for work. In the October 1845 issue of $D e$ Reformatie he declared that he would announce his opinion regarding emigration in the next month's issue. ${ }^{9}$

Scholte's public pronouncement appeared as forecast in the November 1845 issue of De Reformatie. He warned Christians to test themselves before deciding to emigrate. "If temporal advantage is the sole or the most important incentive, we can with certainty advise such people against emigration." Those who were thinking of leaving the Netherlands should examine their hearts to see whether they were acting in accordance with God's command, which "is the same in all lands and under all circumstances: 'Humble yourselves therefore under the mighty hand of God, that He may exalt you in due time." Scholte does not seem to have made up his own mind at this time, but the rapidly growing desire of his followers to leave the country called for immediate action. ${ }^{10}$

Scholte wrestled within himself for evidence of God's guidance. He found the supreme principle for the lives of Christians in Matthew 6:33, "But seek ye first the Kingdom of God and His Holiness, and all these things shall be given you besides." Another scripture verse, Matthew 10:23, offered more direct advice: "When, however, they persecute you in this town, flee to the next." Scholte interpreted this passage to mean that Christians need not wait for unbearable oppression before they should leave. He had finally concluded that emigration under certain conditions was not contrary to God's

\footnotetext{
${ }^{9}$ Scholte Manuscript (undated, Scholte House, Pella, Iowa); Oostendrop, Scholte, 150; H. P. Scholte, ed., De Reformatie, Series III, 1 (1845), 240.

${ }^{10}$ Lucas, Netherlanders in America, 151-152.
} 
word. But he remained unsure whether conditions in the Netherlands truly warranted emigration. $\mathrm{He}$ attributed the nation's unrest to the application of the Code Napoleon rather than to the law itself. Briefly, Scholte detected a change in the official attitude regarding enforcement and hoped that the King would evince a more liberal attitude. His optimism soon faded, however, and he yielded his opposition to emigration by spring of $1846 .^{11}$

Determined to remain loyal to the House of Orange, Scholte entertained the idea that his separatist followers might settle in the East Indies. "Before I resolved to direct the attention for emigration to the United States, I have tried with some others to induce the Netherlands Government to give us occasion to make free settlements in the island of Java but it seemed that the Government did rather wish to avoid such settlements." Scholte met in the Hague with Otto Heldering, the minister of the colonies, and their conversation ended Scholte's remaining hesitations. He began to criticize openly many aspects of the government. "The attempt to receive from our government a free Christian colony in the East Indies has, as far as I am concerned, utterly failed (unless one wishes to console himself with vain expectations)," Scholte declared. "It is decided-we shall leave our mother country and emigrate to America." 12

After ten years of persecution, Scholte, against his own wishes, had been forced to abandon his dream of the "Reveil for a Holy Holland." He endorsed the migration for his own friends and congregation: "The Lord has prompted me to make a definite investigation for my fellow countrymen who are emigrating to the New World, ". he wrote in December 1846. "I am convinced that a settlement in some region there will have, by the ordinary blessing of God, excellent temporal and moral results, especially for the coming generation. ... Should it then excite much wonder that I have firmly resolved to leave the Netherlands and

${ }^{1}$ H.P. Scholte, "Een Woord van de Landverhuizing," De Reformatie, Series II (1846), 88-89.

${ }^{12}$ Scholte Manuscript: H. P. Scholte, Nieuwjaarsgeschenk aan Nederland, een Ernstig woord aan Vorst en Volk (Amsterdam, 1847), 23, 27 (hereafter cited as Nieuwjaarsgeschenk). 
together with so many Christian relatives adopt the United States as a new fatherland?" 13

Scholte continued, to the people of the Netherlands:

There I shall certainly meet with the same wickedness which troubles me here; yet I find also opportunity to work. There I shall certainly find the same, if not greater, evidence of unbelief and superstition; but I shall also find constitutional provision which does not bind my hands in the use of the Sword of the Spirit, which is the Word of God; there I can fight for what I believe without being disobedient to the magistrates and authorities ordained by God. There I shall find among men the same zeal to obtain this world's goods; but I shall not find the same impulse to get the better of one another, for competition is open to all; I shall not find the same desire to reduce the wages of labor, nor the same inducement to avoid taxation, nor the same peevishness and groaning about the burden of taxation.

There I shall find no Minister of Public Worship, for the separation of Church and State is a fact. There I shall not need to contribute to the support of pastors whose teachings I abhor. I shall find no school commissions nor school supervisors who prohibit the use of the Bible in schools and hinder the organization of special schools, for education is really free. I shall find there the descendants of earlier inhabitants of Holland, among whom the piety of our forefathers still lives, and who are not prepared to give advice and aid to Hollanders who are forced to come to them. ${ }^{14}$

Scholte concluded his "New Year's Gift" of 1847 to the people of the Netherlands by ending with a prayer. Calling on the Lord God who is "the expectation, home and refuge of His people," Scholte pled his case: "Thou knowest, O Lord, the word spoken in Thy name is not accepted as such in the Netherlands, now it is even adjudged exaggeration. ..."15 Closing his prayer, he pled for himself and his people: "O God, as the obdurancy increases, and Thy judgment challenged by a sinful and adulterous gene-

${ }^{13}$ Vander Zee, Hollanders of Iowa, 39; Van Stigt, Geschiedenis van Pella, Iowa en Omgeving, 24; Nieuwjaarsgeschenk, 48.

${ }^{14}$ Nieuwjaarsgeschenk, 48-49; Vander Zee, Hollanders of Iowa, 40; Van Stigt, Geschiedenis van Pella, Iowa en Omgeving, 25.

${ }^{15}$ Nieuwjaarsgeschenk, 52; Van Stigt, Geschiedenis van Pella, Iowa en Omgeving, 26. 


\section{Scholte and the Land of Promise}

ration, fulfill Thy promise, save all in the hour of their affliction. For those who have kept the Word of Thy long suffering, prepare them another Pella, and let it truly be the watchword of this people. 'In God is our hope and refuge.'"16

Scholte had resigned himself to leave the Netherlands. "After an honest investigation of the condition of our Fatherland," he wrote his dear friend, Groen van Prinsterer on May 15, 1846, "I can no longer oppose the desire to emigrate." He pointed out that "in North America land is lying idle; there is complete freedom of religion and education; indeed, if the number of emigrants is at all considerable and if they stay together and buy some extensive stretch of land, even the control of the local government will remain in the hands of the colonists."

By the summer of 1846 , Scholte published formal statements of his plans for founding a new settlement. It was to be a charitable venture. Colonization would be definitely Christian even if that requirement countered good business practice. Only Godfearing people could receive assistance. Every effort would be made to help those who were not seceders, but members of Scholte's flock would have first consideration. In religious communion and the colony's organization "the Word of God would form the sole rule, foundation and guide, and no adherence would be required to ancient or recent forms not enjoined of God." The venture would probably include religious service and Christian instruction.

Scholte drew up guidelines for land purchase. The selected land should support the usual crops raised by Dutch farmers, including wheat, oats, flax, and hemp. Cattle raising would also be considered. The site should be near navigable rivers so that the Dutch settlers might export their products and import other necessities. He duly warned that one hundred guilders would be required to defray each emigrant's travel expenses and each should bring an adequate supply of clothing, tools, and equipment. Scholte urged wealthy Christians who would not be able to leave immediately to buy lands for possession later since the colony was bound to succeed. "When one reads the history of the development of the United States of North America," he

${ }^{16}$ Ibid. 
wrote, "it appears almost unbelievable how speedily a little energetic enterprise results in favorable prosperity: Writers who have made fun of America and minimize the country as Charles Dickens has done, incidentally give such testimony of what they have seen and heard that an impartial leader is compelled to state that America must be a good country." 17

Scholte considered several locations in the United States, among them Iowa, Illinois, Indiana, Ohio, and Wisconsin. He also considered Texas, but ruled it out because it.was legally a new slave state. On July 2,1846, he wrote to the King that he planned to leave on an exploratory trip to the United States in the fall "to investigate ... and to see with his own eyes whether the written reports were the whole truth. ${ }^{18}$

Scholte suggested that preliminary meetings be held in Leerdam and Utrecht during July and August. An emigrant association of nearly seventy well-to-do families, mostly from the province of South Holland, formed. Many more families from other provinces joined later so that the society numbered around 1,300 members. The Utrecht Association decided that the newly organized states of the Mississippi Valley region presented the best choice for Hollanders, and lowa seemed to be the general choice of all. Under Scholte's influence, association members resolved that the location finally selected should offer security from Indian attacks, a healthful climate, opportunity to practice various branches of agriculture, and finally, accessibility to markets. Iowa met that test. ${ }^{19}$

A committee of delegates selected from various Seceder congregations met in Utrecht on September 4, 1846, and drew up rules to govern the emigration movement. The "committee for the regulation of emigration" was to gather additional information about the United States, draw up lists of prospective emigrants, and make other departure plans. ${ }^{20}$

Meanwhile, within his own family, Scholte faced a personal

\footnotetext{
${ }^{17} \mathrm{H}$. P. Scholte, "Aanmerkingen betrekkelijk de Landverhuizing naar Noord-Amerika," De Reformatie, Series III, 2 (1846), 355-59.

${ }^{18} \mathrm{H}$. P. Scholte to King Willem II (last letter), 2 July 1846, Scholte Papers.

${ }^{19} \mathrm{H}$. Picard, Belangrijke berigten uit Noord-Amerika (Amsterdam, 1847), iii; Cyrenus Cole, "A Bit of Holland in America," Midland Monthly 3 (1897), 117.

${ }^{20}$ "Aanmerkingen betrekkelijk de Landverhuizing nar Noord-Amerika," $D e$ Reformatie, Series III, 2 (1846), 119-120.
} 
crisis, "a painful event," which kept him from making the proposed fall trip to America. Writing to his friend, Groen van Prinsterer, on October 9, 1846, Scholte told of the critical illness of Mareah, his wife, and of the death of their baby boy. The family attributed Mareah's illness to the shock of Scholte's announced intentions. She apparently could not bear to leave her own country and her family. When a maid announced that "Dominee and all of us are going to America right away!" she had swooned. Dominee H. F. Kohlbrugge wrote Scholte's old friend, W. De Clercq, of a rumored scandal: "Scholte and his wife have reached such disagreement upon the last moment before migration that they have been after each other with knives, so that the police had to be called." Undoubtedly exaggerated, Kohlbrugge's report contained the truth of Mareah's unwillingness to leave. To encourage his wife, the Dominee pictured an America of great prosperity and agreed to include Hubertina, her sister, in the move. He promised to build a beautiful new home and to reproduce their large Dutch library in every detail. But the planned departure brought unhealed division between Scholte and his father-in-law. Opposition within his own family created heartache for this leader. Family difficulties added to the growing responsibility for hundreds of emigrants daily joining his plan to make his emotional load almost unbearable. ${ }^{21}$

On Christmas Day 1846, the Christian Association for Emigration was formally organized in Utrecht. Scholte was unanimously elected president and Antoinie Jan Betten, the seceding pastor from Noordeloos, in Zuid Holland, was chosen vice president. Four advisors were also unanimously chosen to complete the Board of Control: J.F. Le Cocq from Amsterdam, A. Wignij from Utrecht, G. G. Overkamp from Leerdam, and Jan Rietveld from Noordeloos. Isaac Overkamp, tutor to Scholte's children and proofreader for his magazine, De Reformatie, was chosen as secretary. The board fixed late March or early April 1847 as the best time for their departure. ${ }^{22}$

Scholte and the board directed the policies of the association, together with actual arrangements to transport and settle the

${ }^{21} \mathrm{~J}$. Van Lonkhuizen, Herman Friedrich Kohlbrugge en zijn prediking in de lijst van zijn tijd (Wageningen, 1905), 199, note 1.

${ }^{22}$ "Berigten aangaande de Landverhuizing naar Noord-Amerika," De Reformatie, Series III, 3 (1847), 338-340; Vander Zee, Hollanders of Iowa, 44. 
Hollanders in one of five midwestern states. The council chartered ships, formed an administration to aid the travelers on board, and arranged for collection of dues and payment of all expenses. Once in the United States, they were to choose the actual site for settlement; buy the land, and administer its division among the settlers. The board would continue to function even after the colony was established to record all marriages, births, and deaths. But there was to be a strict separation of church and state. The board was to have no connection with religious matters, those were reserved for others who wished to organize a church. A constitution had been adopted at Christmas 1846 and preparations to leave proceeded on schedule. ${ }^{23}$

Scholte had received a long letter in Utrecht from Hendrik Barendregt at St. Louis, who had sailed in October without Scholte. Barendregt's letter greatly encouraged the Dominee and those who were preparing to leave. America was obviously the place for the poor Hollander, wrote Barendregt, because there was a large demand for labor and wages were high. He asked Scholte to tell an acquaintance "that he could live better as a baker here in St. Louis than he could as a townsman in Rotterdam." Moreover, he continued, "One finds no shocking immorality here, as in Rotterdam or other cities of Holland. ${ }^{24}$

Sometime between December 10 and December 19, 1846, Scholte had sold his house and had received 5,000 guilders for his church building. The church sale brought "such a high price that not only could the debt be paid, but the needy members of the congregation for the greater part helped over to the United States." Most of his congregation and two of the elders were planning to leave also. ${ }^{25}$

A few weeks before the group left the Netherlands, an "Evangelical Christian" wrote a lengthy parting poem in opposition to Scholte's abandonment of the vision for a Holy Holland. Schism is always unchristian, the poet wrote. He had opposed state per-

${ }^{23}$ H. S. Lucas, ed., "De Artikelen van Scholte's Vereeniging ter Verhuizing naar de Vereenigde Staaten," Nederlands Archief voor Kerkgeschiedenis, New Series, 38 (1951), 179-187; Henry S. Lucas, Netherlanders in America, 158-159.

${ }^{24}$ H.P. Scholte, ed., "Brief uit Noord-Amerika," De Reformatie, Series III, 3 (1847), 355-367.

${ }^{25}$ Scholte Papers; H. P. Scholte to G.G. Van Prinsterer, 17 December 1846. Politieke Correspondentie van G G. van Prinsterer, Rijksarchief, The Hague. 
secution and championed freedom for the seceders, but Scholte "he could not stomach." He accused the Dominee of spurning his fatherland's device EENDRAGT MAAKT MACHT [In Unity lies strength] and creating national division:

Farewell, you restless wanderer,

Too long your feet have stood, Upon the land, that, as the fathers say,

Only unity could have made good.

Farewell; to the bewitched land of freedom

That praises unbelief and lies

Making, in its howling tongue confusion

Even higher Babel's tower rise.

Yea, you have made the wound

Which your hand cannot heal;

You've unleashed the driving rage

Which your voice cannot conceal.

The masses now are cursing

And bitter spite drives yon your steps

Since here they all have left you.

Still we'll not send a curse

But a prayer to follow thee!26

SCholte AND his Family left Rotterdam on April 8, 1847 aboard the steamboat Sara Sand. They traveled by way of London and Liverpool and were the first of their company to arrive in America in May after a thirteen-day voyage. Several days in Boston gave the Scholte family time to rest and gain their first impressions of the new country. After placing his wife and children in the Connecticut home of John Norton, Scholte proceeded on to Albany and then to New York City. ${ }^{27}$

To set out for the "promised land," the association board had chartered four three-masters to carry nearly eight hundred emigrants to the port of Baltimore. The Catherine Jackson was the first ship to leave Rotterdam, with 169 passengers aboard, and the first to arrive in the new country on May 22. The Nagasaki

${ }^{26}$ Afscheidsgroet aan H. P. Scholte bij zijn vertrek naar Noord-Amerika, door een evangelisch Christen (Maart, 1847); Oostendorp, Scholte, 153-154.

27J. Vander Meulen, TerNagedachtenis van Rev. C. VanderMeulen, 53, quoted in Oostendorp, Scholte, 153; H. Picared, Belangrijke Berigten uit NoordAmerika, 7-11. 
sailed on April 11 with 200 passengers; the Maastroom followed with 197 aboard; and, finally, the Pierter Floris, left Amsterdam with 222. Two advisors exercised general supervision of each ship and conducted religious services. ${ }^{28}$

The ocean voyage lasted seven or eight weeks. Terrible spring storms buffeted the ships. Despite minor discomforts, however, such as taking turns to cook meals on the ship's stove, the Hollanders enjoyed a generally peaceful trip. No major mishaps marred the crossings, but two adults and eighteen children died and were buried at sea. Several children were also born. ${ }^{29}$

The four small ships landed safely in Baltimore harbor-the first late in May and the last early in June 1847. Baltimore, a large city with make-shift buildings, chickens, hogs, and cattle running loose in its muddy streets, shocked the Dutchmen who were used to well-kept roads in Holland. But if these Dutch people were chagrined at their first sight of an American city, Americans were astounded by the appearance of both ships and people newly arrived in the harbor. After visiting the first ship to arrive, one newspaper reported:

We have seen many emigrant ships, but we never saw one more cleanly in its appearance than this, and we have never yet seen in any ship so fine a body of emigrants. ... They have been remarked as beyond comparison, superior to any ship load which has reached port. They are in fine health, well clad, and have an abundance of money to locate themselves. On inquiry yesterday, we learned that this body is but the vanguard of several thousands. ... They come here to find religious liberty, and if the "vanguard" is a specimen of the whole, any country might be proud of such citizens. ${ }^{30}$

Scholte eagerly awaited news of the arrival of the first ship in Baltimore. Exploiting newly arrived foreigners was a regularly practiced American game. The "ronselaars," as he called the runners at American ports, were "so accustomed to see incoming ships filled with half-starved Irishmen or ill-smelling Germans

${ }^{28} \mathrm{~K}$. Van Stigt, Geschiedenis van Pella, Iowa en Omgeving, I, 89-95.

${ }^{29}$ Vander Zee, Hollanders of Iowa, 47.

${ }^{30}$ Baltimore Sun, 27 May 1847, quoted in B. H. Wabeke, Dutch Emigration to North America, 1624, 1860. The Netherlands Information Bureau, No. 10, 10 Rockefeller Plaza, New York City, 131. 
that the rumor of the coming of so many Hollanders with money in their pockets and clean looks besides, goaded their zeal anew to give chase after what people here have already quite generally learned to call 'willempijes' [ten-florin gold pieces]." When he received the telegram announcing the arrival of the first ship, Scholte hastened by train to Baltimore where he "could rejoice in the safe arrival of those with whom I should henceforth live in common." ${ }^{31}$

Scholte, well provided with letters of introduction from America's minister to the Netherlands, had enjoyed a warm welcome to the new country while awaiting his fellow countrymen. He had found access to officials and other influential persons who offered information for the new colony. The American minister at The Hague wrote a letter of introduction to the poet Henry Wadsworth Longfellow. Scholte had expressed the desire to be made known to some of the minister's "litterary friends" in Boston and in New York. Requesting Longfellow and his wife "to receive him kindly and to facilitate him the means of intercourse with the most 'distinguished ecclesiastics of your City [Boston]," the American minister introduced the Dutch clergyman as "a man of great learning, eminent piety and exemplary private virtues" who had left "his Country to seek for himself and his Congregation, a Sect of which he is, at the same time, the founder and the Apostel [sic], a freer exercise of their mode of worship in our Republic." Scholte experienced no spiritual communion in the "capital of American rationalism." He did not evidently find Longfellow and his wife at home, and, therefore, did not visit anyone of special interest to himself. But he did find great interest in Dutch emigration to America. ${ }^{32}$

To the Roman Catholic Bishop John Hughes, later archbishop in New York, the American diplomat in the Netherlands recommended Scholte "as a person of eminent tho' mistaken piety and equally known here and respected for litterary [sic] talents and private virtues." To the future leader of the Roman Catholic Church in the United States, the American official admitted there was another motive. "I confess too that I felt a pleasure by

${ }^{31}$ Vander Zee, Hollanders of Iowa, 49-50.

${ }^{32}$ Auguste Davyae, The Hague, to Henry Wadsworth Longfellow, 15 April 1847, Scholte Papers; H.P. Scholte, Eene Stem uit Pella (Amsterdam, 1848), 9 (hereafter cited as Eene Stem uit Pella). 
introducing him to your acquaintance, to remove any prejudice which, as an original Calvinist, he may still retain in relation to our Church, by communing with its most distinguished minister in America," he wrote. He continued to explain that these Dutch emigrants were no ordinary European refugees. "The emigrants whom Doct. Scholte leads to what, for them, is, indeed, a land of promise, are not destitute adventurers. Many are what we would call snug farmers, others skillful mechanics; all industrious and sober. In fact their tennets (ultra-Calvinism) rendered them sturn [sic] and unsocial. ${ }^{\prime 33}$

Scholte traveled first to Albany, after the short stay in Boston, and the Reverend Isaac Wyckoff warmly welcomed this newcomer whom he judged "a worthy man, who will be an honor to our country, and an aid against the Man of Sin, and every form of false religion...." Wyckoff invited him to preach in Dutch. He had such a wonderful stay in Albany that he had to admit: "Had I not been bound to our Association, I certainly could not have withstood the pressure of persons who urged me to stay in the State of New York and once more to hold regular services in the Dutch language." In Albany the Dominee had an experience which he would never forget. Visiting the newly convened state legislature at Albany, Scholte was recognized by one of the members. He reported, "I was compelled to take a seat in the midst of them. How different from Holland! In the land of our birth branded and treated as a despised congregation, misunderstood by everyone, shoved aside, trampled upon and bruised; in the land of strangers and above all in its most respectable part, honored and treated as a costly gift of God to improve their country. ${ }^{34}$

In New York City, where his good friend and correspondent the Reverend Thomas De Witt lived, Scholte preached several times in different churches. More invitations arrived for him to return to preach in Albany, but association business required that he decline the offers. From New York, Scholte journeyed south in search of more information. He visited Washington,

${ }^{33}$ Auguste Davyae, The Hague, to the Reverend Bishop John Hughes, 15 April 1847; Auguste Davyae, The Hague, to Judge Van de Pol, 15 April 1847, Scholte Papers.

${ }^{34} \mathrm{~J}$. Wychoff to “Brother Fisher," New York, 13 May 1847, Scholte Papers; Eene Stem uit Pella, 10-12. 


\section{Scholte and the Land of Promise}

D.C., and collected information on all parts of the country. Government officials offered him every kind of printed information, which, together with various state maps of saleable land, he received after his return to New York at no cost. This information, in addition to other sources, turned Scholte's attention away from settling in Michigan. As early as May 1847, Scholte had concluded that lowa or a part of Illinois was best suited for the association's needs and he judged "that a good locality is recommended by telling not what people may do but what they have done and are doing. ${ }^{\prime 35}$

Everywhere American Christian people welcomed them with warm, loving arms. "They have come from Holland to our land of liberty, as the Pilgrims \& Huguenotts [sic]," wrote one admiring new friend. "I believe," wrote Scholte later, "that in general they cherish too lofty opinion of us. In their conversation and newspapers we are represented as resembling the God-fearing Pilgrims who first settled in the United States. They regard our coming to this land of civil and religious liberty as one of God's blessings on their country. ..." But all this warm reception made Scholte reflect deeply: "Often times a sense of shame and embarrassment comes over me when I stop to look at myself and our Association, and there consider the high thoughts which people entertain of us. ..." In their willingness to help, Americans were said to put these Dutchman to shame, and Scholte could say: "In this way America treats the Hollanders who were so oppressed in their native land in matters civil and religious that they were forced to leave. That God had done for us. ${ }^{\text {"36 }}$

As soon as each immigrant arrived at Baltimore, plans were made to leave as soon as possible for St. Louis. Scholte remained there until the last association members were cared for and then he, too, left, with his family for St. Louis, arriving on June $6 .{ }^{37}$

It was a long journey to St. Louis. The exciting new experience took the newcomers westward through Pennsylvania, along the Pennsylvania Canal. They journeyed first to Columbia by train.

${ }^{35}$ Eene Stem uit Pella, 2, 11-14; Vander Zee, Hollanders of Iowa, 59.

${ }^{36}$ Sarah P. Docenus, New York, to the Reverend J. W. Dubois, Cincinnati, Ohio, 16 June 1847, Scholte Papers; Eene Stem uit Pella, 11-12; Vander Zee, Hollanders of Iowa, 56.

${ }^{37}$ S.A. Sipma, Brief van. . .aan de Ingezetenen van Bornwerd (Dockum, 1848), 4-5, 7-8. 
Leaving the train, they crossed a covered railway bridge and, with their baggage, crowded aboard canal boats. These boats moved up the valley, passing Harrisburg, to the Juniata River. One hundred and thirty locks lifted the boats and carried them up to Hollidaysburg. With their goods transferred to freight cars, the passengers boarded a train to Johnstown; through an aweinspiring mountainous scene. At Johnstown, Pennsylvania, they transferred to canal boats again and slowly passed through more than a hundred locks, down the river to Pittsburgh. And here, Scholte had the pleasure to preach in the Dutch language to part of the association. Then they journeyed by boat down the Ohio River to St. Louis. ${ }^{38}$

St. Louis was the center of the river transportation system on the great Mississippi north of New Orleans, and of overland commerce in every direction. The city was a bustle of activity and the Hollanders found places to stay only with difficulty. They rented rooms and houses all over town. Scholte secured "a good house" for his family. Most of the immigrants found work, but, for some, America was not the utopia they had expectedwhere life's necessities were free without work. ${ }^{39}$

Scholte believed that Iowa's limitless prairies would provide the lands necessary for good farming. Plans were then made to send out a special committee to locate a site. On July 20 and 21 the committee-H.P.Scholte, Teunis Keppel, Isaac Overkamp, Jan Rietveld, and Gerrit Van der Pol-traveled by steamboat to Keokuk in the new state of lowa. The committee journeyed fiftyfive miles northwest of Keokuk to the land office at Fairfield. Scholte was convinced that the region where squatters had prospered would be the best selection for the new site. Providentially, Scholte believed, he met a Presbyterian pastor on Sunday, July 25. The next day, this man introduced Scholte to the Reverend Moses J. Post, a Baptist minister who had been in Iowa Territory since 1841. Post had acquired unrivaled knowledge of Iowa land and he told Scholte of two desirable sections, if the settlers there would be willing to sell their claims. Indeed,

${ }^{38}$ See for the canal route, A. B. Hulbert, Historic Highways of America, Vol. 13: The Great American Canals, Vol. 1, The Chesapeake and Ohio Canal (Cleveland, Ohio, 1904), 184; Eene Stem uit Pella, 11. 8.

${ }^{39}$ Sipma, Brief van. . .aan de Ingezetenen van Bornwerd, 9; Eene Stem uit Pella, 
the settlers were willing and received $\$ 1.25$ an acre in gold. Serving as guide, Post led the committee to Marion County and on Thursday, July 29, near noon, they arrived at the rise of land which would be called "Pella" in a few weeks.

When the five committeemen returned to St. Louis in early August and reported the results of their trip, the excited Hollanders prepared to leave. Newspapers praised the choice of land and declared that the region between the Skunk and the Des Moines rivers was one of the best sections in the whole new state of Iowa. Scholte was very pleased. Soon there would be a "Pella," a city of refuge.

It would be very difficult for the whole colony of eight hundred people to subsist in an unsettled countryside. It was believed, therefore, wiser to have only a part, around five or six hundred, go ahead and prepare the way for those who would follow. As soon as they were ready, the vanguard left St. Louis and spent Sunday, August 15, on the steamboat headed up the Mississippi River to Keokuk. Here, a large number of curiosityseekers greeted the arrivals. Some just gazed at the strangely dressed and quaintly speaking foreigners; others hoped to enrich their own pockets with some now-famous Dutch gold pieces. But a somber note marked the landing-upon arriving the Hollanders buried three of their band who died after leaving St. Louis. ${ }^{40}$

Only fifteen years before, Indians had wandered over the same trails which the travelers now took up the rich green valley. One Mahaska County observer noted: “And when they came along the road with various kinds of teams, we gazed in wonder at their quaint and unfamiliar appearance. Their dress was strange to us. Women were perched on high piles of queer looking chests and boxes and trunks, many of them wearing caps, but no bonnets. Some of the men, and women too, wore wooden shoes. ${ }^{.41}$

At last, on August 26, they arrived at the rise in the land which the committee had selected for the new town. The spot was marked by a hickory pole with a shingle nailed at the top

40Vander Zee, Hollanders of lowa, 66.

${ }^{41}$ Semira A. Phillips, Proud Mahaska, 1843-1900 (Oskaloosa, Iowa, 1900), 239-240. 
inscribed with the word chosen by Scholte - "Pella." Scholte later described the town's location:

Pella is beautifully situated on an eminence from which may be had a general view of the surrounding country. ... We feel confident Pella will become one of the most attractive places in the State, where honest and industrious families can enjoy life and liberty, without necessity of defending; acquire and possess property without necessity of protecting, except by commodious wire fences against the increasing stock of cattle; and feel grateful to a Kind Providence who cast their lot in such a good place, where safety and happiness are felt and enjoyed without necessity of first pursuing and obtaining. ${ }^{42}$

THE SMAll band OF REFugeEs was merely the beginning of Dutch immigration to Iowa. In the years prior to the American Civil War, Pella and the colony's offshoots, Orange City, Sioux Center, Maurice, Hospers, Remsen, and other northwestern Iowa towns witnessed the growth of the state's Dutch population to 2,615 by 1860 . Ten years later, the Dutch became Iowa's fifth largest emigrant group with a population of 4,513 .

Meanwhile, Pella prospered and Scholte led a very busy life. As the editor of the Pella Gazette, he wrote editorials and evaluated many questions of interest to the town and the state. He was a banker, a broker, a land agent, a notary, and a clergyman and friend. In addition, he served as a leader of Pella's educational system and gave his time, money, and land, to build Central College, a Baptist institution.

By the 1850s, the politics of slavery, secession, and war attracted the attention of the nation, as well as Scholte and the Iowa Dutch. His editorials on slavery were published in book form and created statewide attention. These antislavery articles were part of the reason he was chosen as a delegate-at-large from lowa to the 1860 Republican National Convention in Chicago. At this "Wigwam" convention, Scholte urged the Iowa men to change their support from William $\mathrm{H}$. Seward of New York to Abraham Lincoln of Illinois. Assisting the Republican national central committee in the 1860 campaign, translating campaign

\footnotetext{
${ }^{42}$ H. P. Scholte, Tweede Stem uit Pella (s'Bosch, 1848), 7-8; Eene Stem uit Pella, 85-89; Pella Gazette, 1 February 1855.
} 
material into Dutch and German, Scholte journeyed to Springfield, Illinois to meet the President-elect. Lincoln was pleased with his "good Dutch friend," invited him to attend his inauguration in March 1861, and Scholte made the long trip to the nation's capital.

In less than twelve years after arriving in Iowa, Pella Dutch boys joined to fight for the Northern cause in their newly adopted homeland. Loyal to the men of his colony, Scholte promised each returning Pella soldier a lot on which to build a house. In the aftermath of war, 129 Pella Civil War veterans claimed Scholte's promise.

During the last years of the civil conflict, Lincoln invited Scholte to become the new American minister to Austria. Scholte weighed the decision carefully, still believing he could be of some help to the Pella colony. Before Scholte responded to the invitation, the President wrote again to inform him that the opportunity was no longer available-the U.S. Senate had passed a bill which provided that only native-born Americans could serve as ministers to foreign countries.

In the last days of his life, Scholte declared that he had made his choice for Iowa, and added, "I am not disappointed, as far as the natural condition is concerned." It was an excellent site for the new colony and had prospered. But he added, "I should however not complain if we could have a little more well educated society." He missed the fellowship of scholars which he had enjoyed in Europe and also on the American east coast. But they had made a Pella. ${ }^{43}$

Twenty-one years after he founded the settlement, Scholte became "indisposed" for a few days. On the evening of August 25,1868 - just one day before the anniversary of the town's founding - he began to complain of pain in his left side. Mareah, his wife, massaged him with what he believed was the proper remedy to help relieve the pain. But the pain increased and within a few minutes he was dead-at the age of 62 years and 11 months. In his obituary, Mareah noted that he had proclaimed God's word since the days of his youth. In God's own hand, he had become the personal instrument used to the salvation of many souls, and his many writings

${ }^{43}$ Scholte Manuscript. 
still contained the power of God. "I can see him go in the happy belief that I shall see him again with his Lord and Saviour," she announced. ${ }^{44}$

"That Pella is what it is," wrote the editor of the Pella Weekblad, "and that the destiny of its people is cast upon a spot on the earth's surface, the fertility of which has almost no equal, is due in a large measure to the untiring effort and clear insight that the deceased [Scholte] possessed so abundantly under the guidance of God's providence." ${ }^{45}$

${ }^{44} \mathrm{~K}$. Van Stigt, History of Pella, 79.

${ }^{45}$ Ibid., 8. 
Copyright of Annals of Iowa is the property of State of Iowa, by \& through the State Historical Society of Iowa and its content may not be copied or emailed to multiple sites or posted to a listserv without the copyright holder's express written permission. However, users may print, download, or email articles for individual use. 